GEOSPORT FOR SOCIETY
$\begin{aligned} & \text { GEOSPORT } \\ & \text { SOCIETY }\end{aligned}$
Scientific Journal founded in 2014 under aegis of University of Oradea (Romania),
University of Debrecen (Hungary), University of Gdánsk (Poland)
ISSN 2393-1353
Edited by Oradea University Press
1, University Street, 410087, Oradea, Romania
Journal homepage: http://geosport.uoradea.ro/geosport.html

\title{
The appearance of sport as a travel motivation in traveling habits
}

\section{Jordan TÜTÜNKOV-HRISZTOV ${ }^{1}$, Anetta MÜLLER ${ }^{2}$, Anikó MOLNÁR ${ }^{3 *}$}

1. Budapest Metropolitan University, Institute of Tourism and Marketing, Nagy Lajos Király str. 1-9., 1148, Budapest, Hungary, e-mail: tutunkov.jordan@gmail.com

2. University of Debrecen, Department of Sports Management, Böszörményi str. 138., 4032, Debrecen, Hungary, email: muller.anetta@econ.unideb.hu

3. University of Debrecen, Department of Sports Management, Böszörményi str. 138., 4032, Debrecen, Hungary, email: miller.e.annie@gmail.com

* Corresponding author

Citation: Tütünkov-Hrisztov, J., Müller, A., Molnár, A. (2020). The appearance of sport as a travel motivation in traveling habits. Geosport for Society, 12(1), 31-43. https://doi.org/10.30892/gss.1204-056

Article history: Received: 20.01.2020; Revised: 10.02.2020; Accepted: 20.03.2020, Available online: 25.03.2020

\begin{abstract}
Traveling habits and tourism motivations are constantly changing and re-shaping. Because of this reason their examination is indispensable for the tourism industry, as the response to these changes is one of the defining elements of competitiveness and product innovation. In our research, we examined the traveling habits of young workers (average age $=29,1 \mathrm{yrs}, \mathrm{sd}=24,00$ ) in the context of destination choice and sport tourism motivations $(\mathrm{N}=1182)$. The survey found that the most popular destination was the European continent, with $71.5 \%$ of respondents choosing an EU country and 7.5\% choosing a non-EU but European destination. 9.3\% of the respondents have chosen only domestic (Hungarian) destination for their holiday in the past 2 years. The results show that only $36.3 \%$ of the respondents have taken part in a holiday without sport purposes, while the majority of them (63.7\%) have taken part in a sport holiday with some frequency in the last 2 years. There was a difference regarding gender, with significantly more men reporting that they took part in sporting holidays than women $(\mathrm{P}=0.000)$. The most typical sporting activities of these types of holidays were swimming and water sports (22.2\%), cycling (19.4\%) and hiking (11.6\%). In tourism product development, the development of leisure sports is of great importance, as it provides the health, entertainment and active recreation that guests demand, thus influencing the choice of destination.
\end{abstract}

Keywords: travel habits, tourist motivation, sport purposed holidays, sport tourism

\section{Introduction}

Nowadays, nothing illustrates better the steady rise of the tourism industry than the increasing number of tourist arrivals around the world. According to data from the 
World Tourism Organization (UNWTO) (2019), the demand for tourism is growing steadily. World tourist arrivals in 2018 were 1.326 billion, up with 86 million from 2016, an increase of 7\% (UNWTO, 2018), and the 672 million tourists arriving on the European continent in 2017, an 8\% increase over the previous year. In 2018, the world's tourist arrivals already exceeded 1.4 billion, an increase of $5 \%$ compared to 2017. The most popular tourist destination is still the European continent, with 710 million tourist arrivals, with the majority of them arriving in EU countries.

The UNWTO's long-term prediction also indicates a positive trend in the number of tourist arrivals around the world, with an average annual growth rate of $3.3 \%$ per year over the period from 2010 to 2030 and an estimated 1.8 billion tourist arrivals worldwide by 2030 (Tourism Towards, 2030). Several studies report on the importance of the tourism sector in the national economy and its role in stimulating the economy and increasing employment rate (Darabos, 2015; Herman et al., 2017, 2018; Ilie et al., 2017).

Demand is not only expanding but re-shaping as well. The needs of travelers are changing, instead of passive travel, active leisure time activities are getting more prevalent during travel (Smith and Puczkó, 2010; Michalkó et al., 2011; Csirmaz and Pető, 2015; Bíró and Müller, 2017; Lövei and Kalmár, 2017; Lenténé et al., 2019a), as health awareness is appreciated more and more in leisure and travel trends as well as in travel motivations (Sőrés et al., 2012; Müller et al., 2005, 2009; Müller and Szabó, 2009; Lengyel, 2015; 2019; Kalmar et al., 2016; Gödény et al., 2018; Laoues et al., 2019; Lengyel et al., 2019). Several national and international studies report that sport plays a dominant role in travel motivations (Müller and Bácsné, 2018). There are studies that analyze the link between passive sports consumption that is, traveling and spectating sporting events, and travel. Travelers to mega-sport events are found to be highly prone to spending, have a high average length of stay and require a variety of leisure services, with some target groups prefering the packages (Bottero et al., 2012; Bíró et al., 2017; Dansero and Puttilli, 2010; Gibbson et al., 2012; Borbély and Müller, 2015; Bánhidi, 2015; Müller et al., 2016).

Travelers require unique services, entertainment attractions and novel features that also influence the motivation of destination choices (Boda et al., 2018; Ráthonyi et al., 2018; Ráthonyi et al., 2019).

\section{Systematic Review}

In 2018, the Hungarian population spent 347 billion HUF on domestic multi-day tourist trips, an increase of $5.7 \%$ at current prices compared to 2017. Last year, Hungarians spent 888 billion HUF abroad, 8.7 percent more than in 2017 (KSH, 2018). 
According to the KSH's (Hungarian Central Statistical Office) Tourism and Hospitality Analysis of 2018, Hungarians traveled within Hungary in the same number as in the previous year, but for a longer period of time: 14.4 million domestic multiday trips in 2017, the average duration of these increased by 4,1 percent to 60.3 million. According to the data of the domestic tourism trips, with regard to the purpose of the trip, the main travel motive is mostly entertainment, relaxation (61\%) (Bíró et al., 2019a).

In 2018, the Hungarian population made 23 million trips abroad, $12 \%$ higher than in the previous year. Time spent increased by 8.7 percent to 62 million days. The most popular destinations for overnight trips were the neighboring countries, as well as Germany, the Czech Republic and the Mediterranean countries, Italy and Greece.

Many tourism studies have long been concerned with motivation of travel with a considerable amount of research studying leisure tourism (Gnoth, 1997; Chen, 1998; Buckley, 2012; Chang et al., 2014; Bansal and Eisel, 2004; Mahika, 2011).

Several domestic tourism researches confirm the popularity of active tourism products, the demand for which is constantly evolving, that requires the continuous development of services (Sulyok and Magyar, 2014; Michalkó, 2002; Michalkó and Vizi 2002; Müller et al., 2019).

Among the definitions of sports tourism, many authors emphasize that the main purpose regarding travel motivation is to live through the experience of sporting activities, coupled with the purchase of tourism services. The definitions distinguish between active and passive variations of sports motivation, which may be aimed at recreational or competitive sports, or participation in sporting events where the tourist is passive in sporting activities but enriched by the experience of cheering (Hall, 1992; Hudson, 2003; Weed and Bull, 1997; Hinch and Higham, 2001; Kurtzmann, 2005; Gibson, 1998, 2003, 2006; Robinson and Gammon, 2004; Bánhidi, 2007; Dobay et al., 2011; Hudson, 2012; Borbély and Müller, 2015).

Dobay et al. (2018) examined the traveling habits and previous experiences at sports camps of 2965 Slovak and 2404 Hungarian adults. 84.5\% of Slovaks and 92\% of Hungarians participated in summer swimming and water camps, where more than $60 \%$ of respondents (in both nations) gained positive experiences. The survey proved that the destination chosen by the respondents is waterfront, lakeside, with waterbased services, which shows a strong correlation with positive travel experiences during childhood. Those who enjoyed participating in these activities during their childhood still seek to plan their holidays near waterfront, and the sea, where swimming, hiking, and sporting activities dominate. Müller et al. (2007) found and demonstrated that positive attitudes and positive experiences with sports camps will continue to determine sports travel habits and motivation. 
Müller (2009) studied the recreational sports habits of 260 major college students, $43 \%$ of whom stated that they regularly hike during the holidays, which is one of the most typical activities of young adults. Müller and Kórik (2009) examined the leisure habits of bathers in the Northern Great Plain region ( $\mathrm{N}=457)$, with $66.5 \%$ of respondents associating exercise (swimming, water sports) with time spent in the spas.

Lenténé et al. (2019c) studied the recreational needs of guests arriving in the North Great Plain region $(\mathrm{N}=140)$. Their research confirmed that recreational facilities are important to guests during their stay, as $23.4 \%$ of the respondents are influenced by the existence of a recreational program in hotel accommodations and $19.1 \%$ by the existence of sports facilities. $62.4 \%$ of guests found it important to have a recreational program during their stay, and $70.2 \%$ of them participated in it as well during their stay. Hiking and bicycle tours were, according to the guests' answers, the two most important program alternatives to offer guests during their stay. Music and dance-based activities and fitness room offerings were also popular, where the authors clearly pointed out the gender difference. Women preferred yoga, and the treadmill, while men preferred to use free weights.

Lentené Puskás and colleagues (2019d) also confirmed that the offerings of the hotels in the North Great Plain region $(\mathrm{N}=39)$ are in line with active holiday trends, with $35.7 \%$ of 4 -star hotels and $37.5 \%$ of 3 -star hotels offering some type of recreational activities to their guests.

\section{Material and Method}

A questionnaire survey was conducted in Budapest to examine the travel habits of young workers. The questionnaires were filled out on paper and the snowball method was used for sampling. Tourism and Catering students had to fill out a questionnaire with 10 of their friends, which were followed by a short interview. The criteria for participating in the study was that they had to take part in some kind of travel in the past 2 years, ie they could answer questions and travel motivations as tourists. Of the 1,200 completed questionnaires, 1182 were evaluated after data cleaning. We chose Budapest for the survey because the KSH's Tourism and Catering Survey of 2018 showed that the participation of people living in Budapest and Pest, as well as in Central and Western Transdanubia, exceeded 50\%, while data from people living in other areas of the country lagged behind (KSH, 2018). We targeted young adults, as Gibbson et al. (1998), when segmenting sports tourists, found that active sports tourism motivation is the most characteristic of early adulthood.

After the digitalization of the questionnaires, the data were processed using SPSS software. In addition to the basic statistics (mean, standard deviation, median, 
mode) we also performed a correlation study. Due to the sufficiently large number of items a gender connection was examined using the Chi2 test.

The questionnaires were filled out by 1182 person, whose average age was 29.1 years $(\mathrm{sd}=24.00$ ), of whom $41.3 \%$ (488 person) were men and $58.7 \%$ (694 person) female.

\section{Results}

As the respondents have been on holiday as a tourist in the past 2 years, we were interested in finding out what are the most popular tourist destinations that Hungarian tourists have preferred. The results are illustrated in figure 1. As multiple choice was possible, the results are presented in percentages. $9.3 \%$ of the respondents had chosen only a domestic destination as their destination in the last 2 years. The European continent was the most popular destination, with $71.5 \%$ of respondents choosing an EU country and 7.5\% choosing a non-EU but European destination. 5.7\% of Hungarian respondents chose the American continent, 3.1\% the Asian, $2.3 \%$ the African, while only $0.6 \%$ the Australian for their destination.

Destination rankings and KSH 2018 database showed that the US has become a less attractive destination for Hungarians, as the popularity of the United States as a destination has declined compared to previous years. This is due to the fact that prices for overseas flights have not fallen, while flights to European countries have become more favorable, and in the United States the price of accommodation and hospitality is much higher than we have seen in European destinations. Hungarian consumers are price sensitive, which is also true in the products and services market (figure 1).

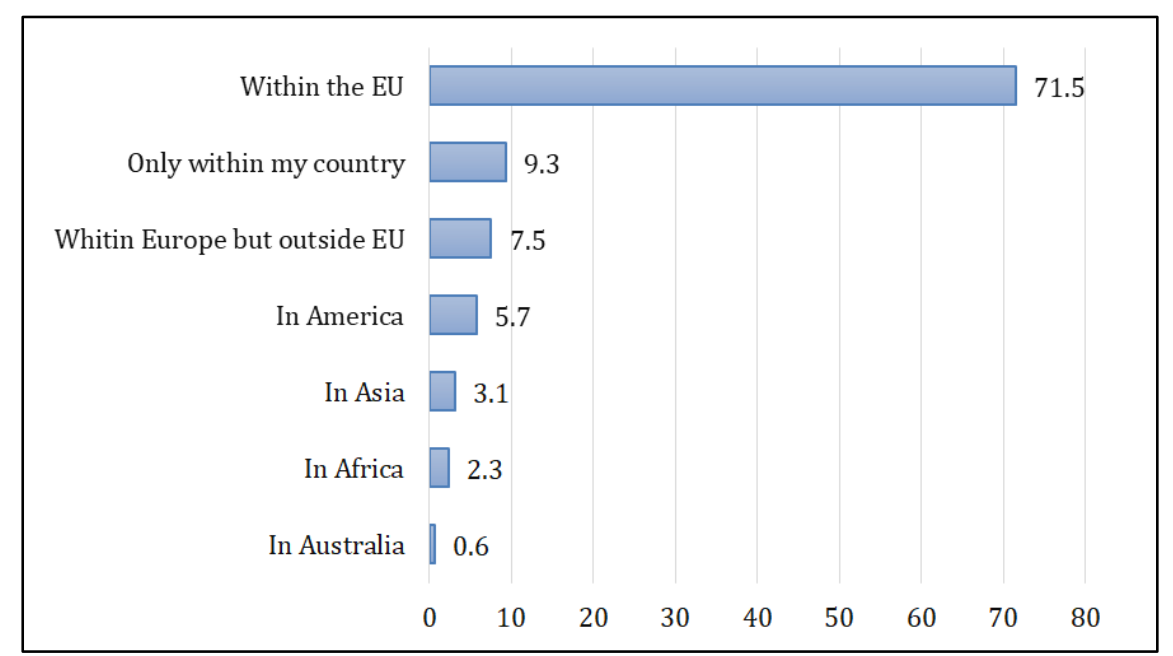

Figure 1. The proportion of trips made in the last 2 years in regard to tourist destinations Source: Own editing, 2020 
We asked how many times during the past 2 years their holidays were related to sports motivation (table 1 ). The results show that only $36.3 \%$ of the respondents have not taken part in a sporting holiday, while the majority of them did (63.7\%). The response of young workers with regards to gender differs, with the Chi2 test showing a significant difference in gender responses. $46.4 \%$ of women (288 people) and only $30.6 \%$ of men (141 people) stated that they did not take part in sporting holidays. Thus, greater activity of men in the field of sporting holidays can be recognized. Men prefer active holidays and some form of sport during their stay. This result coincides with the fact that by examining the recreational sport activity of different target groups, similar results can be obtained, ie in their spare time, men spend more time participating in sporting activities than women (Herpainé et al., 2017; Boda et al., 2019; Kovács, 2011).

Table 1. The evolution of sports vacations in the last two years Source: Own editing, 2020

\begin{tabular}{|c|c|c|c|}
\hline $\begin{array}{c}\text { Participating in sporting holiday } \\
\text { (/times) }\end{array}$ & $\begin{array}{c}\text { Male } \\
\text { person (\%) }\end{array}$ & $\begin{array}{c}\text { Female } \\
\text { person (\%) }\end{array}$ & $\begin{array}{c}\text { All } \\
\text { person (\%) }\end{array}$ \\
\hline Once & $116(25,2 \%)$ & $121(19,5 \%)$ & $237(20,1 \%)$ \\
\hline Twice & $93(20,2 \%)$ & $104(16,7 \%)$ & $197(16,7 \%)$ \\
\hline Three times & $32(6,9 \%)$ & $32(5,2 \%)$ & $64(5,4 \%)$ \\
\hline More & $79(17,1 \%)$ & $76(12,2 \%)$ & $155(13,1 \%)$ \\
\hline I didn't participate & $141(30,6 \%)$ & $288(46,4 \%)$ & $429(36,3 \%)$ \\
\hline All & $461(100 \%)$ & $621(100 \%)$ & $1182(100 \%)$ \\
\hline \multicolumn{2}{|c|}{ chi2 $=1212,7, \mathrm{df}=10, \mathrm{p}=0,000$} \\
\hline
\end{tabular}

The next question examined the frequency of sporting vacations (figure 3). The results show that most respondents chose the annual frequency (once, twice a year and several times a year) for domestic or foreign destinations. It can be stated that the active form of leisure time, the integration of sport into the lifestyle means that these consumers not only demand it every day, but they do not give up sporting or active recreation even during their holiday or vacation.

We asked about the most typical sporting activities on holiday (figure 4). As more than one answer could be given to this question as well, the results are presented in percentages. Swimming, water sports $(22.2 \%)$ are the most common sporting activities. The reason for this may be that most of the vacations are scheduled for the summer period, where water (lake, river, sea, bath) appears to be a central element of motivation. Studies focusing on Spas and Baths also confirm that pool services are one of the most popular elements during spa visits, where the role of swimming as a sport or activity is dominating (Müller et al., 2009; Müller and Kórik, 2009; Bíró et al., 2019b; Lenténé et al., 2019b). Another reason is that recreational swimming is a preventive exercise that supports health (Bíró et al., 2007; Bíró, 2011; Bíró et al., 2015). 


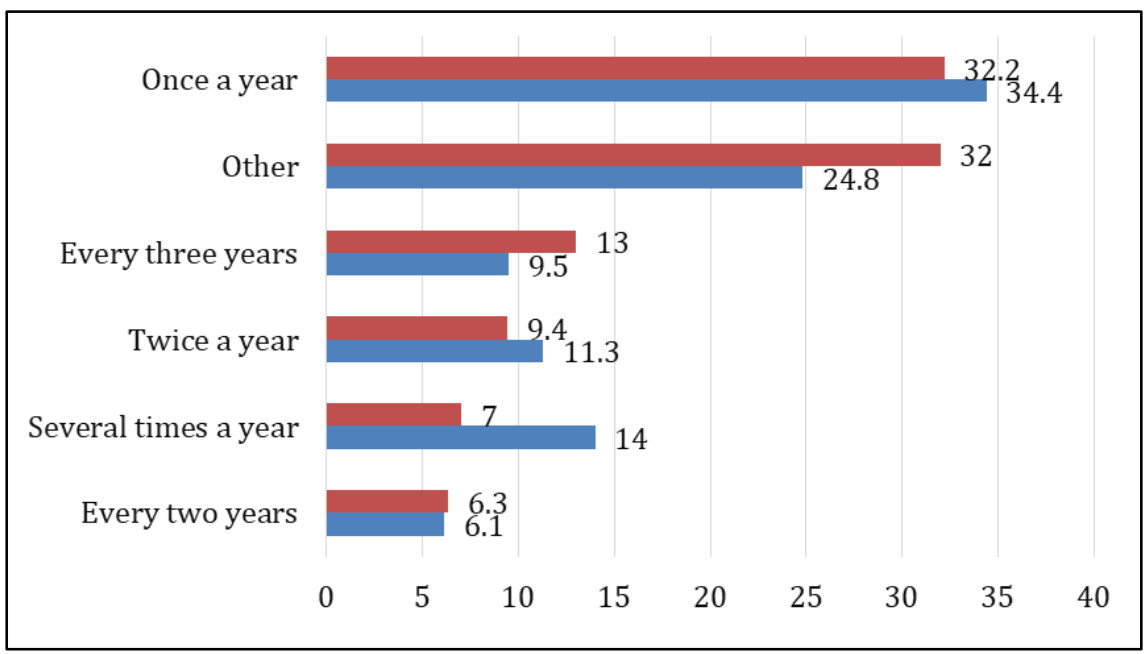

Figure 2. Frequency of participation in sports holidays (\%) Source: Own editing, 2020

The second most popular activity is cycling (19.4\%) the third is hiking (11.6\%). Several studies have confirmed the increasing motivation for cycling and hiking (Ritchie et al., 2010; Sulyok and Magyar, 2014; Lenténé et al., 2019d).

$9.7 \%$ of respondents said that what they do depends on the destination. Winter sports (7.7\%) were also mentioned relatively high. It is true that Hungary has limited opportunities due to the lack of high mountains and low snow cover days, but the surrounding countries offer good opportunities for winter sports and the KSH 2018 publication proved the popularity of this as well. Ball games were marked by only $4.5 \%$ of respondents. As a new type of exercise extreme sports was chose by $3.7 \%$. While $3.4 \%$ of respondents mentioned running, jogging, $2.3 \%$ of fishing and only $0.8 \%$ of horseback riding. $11.7 \%$ of the respondents stated that they were resting passively and did not engage in any sporting activities.

Mosonyi et al. (2013) studied the recreational activities and traveling habits of college students $(\mathrm{N}=140)$ and found that young adults prefer swimming $(76 \%)$ during their travels, as $86 \%$ of their trips are tied to the lakeside or water. $24.7 \%$ of the students go cycling, $46 \%$ hike during the holiday and only $10 \%$ go fishing. These data show that the most typical sporting activities for students were similar to our findings, except that they had a much higher rate of participation in these activities. Winter sports did not appear in responses of the students, probably because it is a costly sport that requires a high discretionary income that most students do not yet have. In high altitude countries in Europe, due to the favorable conditions, winter sports play a much larger role in both recreation and tourism (Alexandris et al., 2009; Matter-Walstra et al., 2006; Dobay and Bánhidi, 2013). 


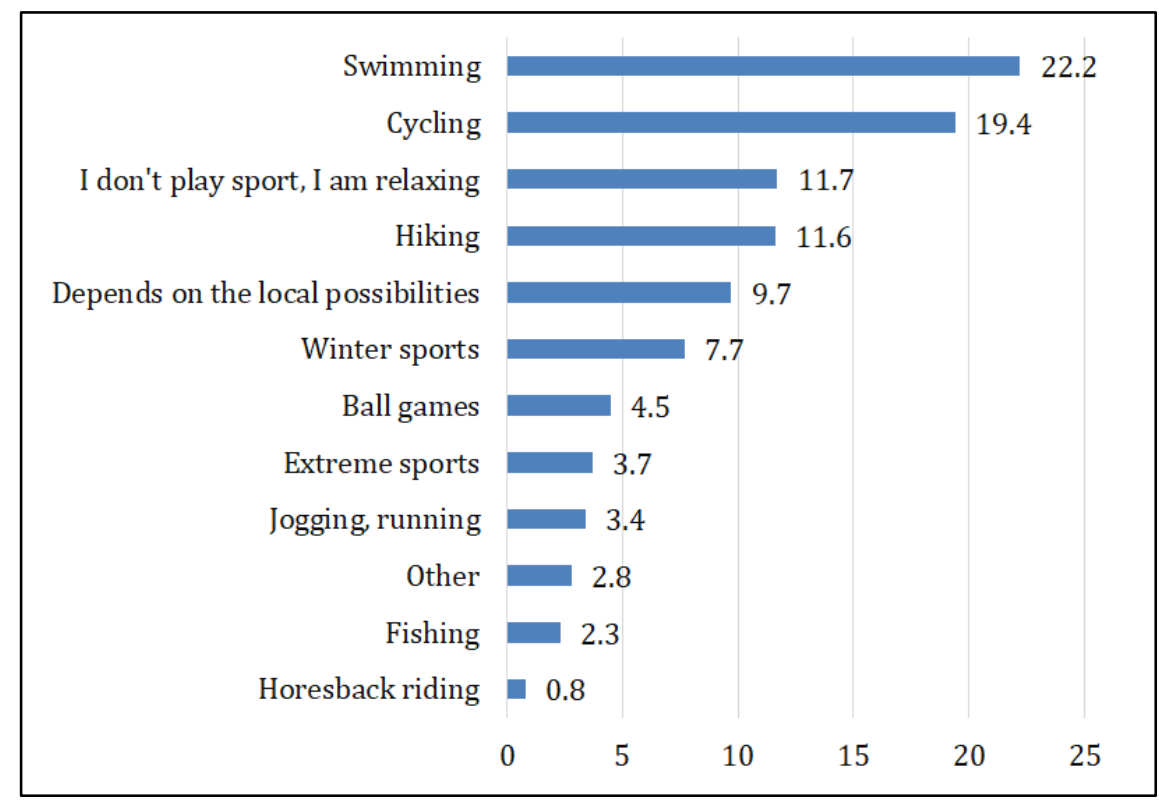

Figure 3. Frequency of participation in sports holidays (\%) Source: Own editing, 2020

In order to examine the motivation of sport tourism, we made various statements, which had to be rated on a 1-5 Likert scale. For example: "To what extent do the following statements apply to you? During the holidays I try to try active, sporty programs."

This statement is more typical for men who prefer a sporty program during their stay. $32.1 \%$ of male respondents stated that this statement is mostly common and $14.1 \%$ that it is completely true, while $20.8 \%$ of female respondents stated this is mostly common and $11.8 \%$ that the statement is completely true. The holiday activity of men is significantly higher than that of women (Chi2 $=1209.7, \mathrm{df}=10, \mathrm{P}=0.000$ ).

The statement: "I choose a tourist destination that is suitable for sports and has sports facilities" is also more typical of men. $22.1 \%$ of them said that this statement is mostly true, while $10.4 \%$ that it is completely true. At the same time $16.7 \%$ of women respondents stated this is mostly common and only $7.2 \%$ answered that this is completely true. Men tend to choose a destination that offers opportunities for sport (chi2 = 1202.2. Df = 10, $\mathrm{p}=0.000)$.

The statement: "Visiting sports as a spectator, during the holidays" is also more typical of men than of women. For $12.4 \%$ of male respondents stated it is mostly true, while for $6.1 \%$ them that it is completely true. $6.8 \%$ of the female respondents stated that this statement is mostly true, while $2.9 \%$ of them that it is completely true. $52.5 \%$ of female respondents that the statement does not apply to them at all, while only 
$39.7 \%$ of men said the same. The difference between the sexes is significant (chi2 = $1211.3, \mathrm{df}=10, \mathrm{P}=0.000$ ), the passive sporting holiday, when traveling is supported by men rather than spectating.

Next statement: "In the summer, I prefer water sports during the holidays" is also more typical of men, as $28.2 \%$ of men, $24.1 \%$ of women fully agree, $24.8 \%$ of them states this is mostly true and $21.4 \%$ that it is completely true, which is a significant result ( $\mathrm{chi} 2=1186.5, \mathrm{df}=10, \mathrm{p}=0.000$ ).

The statement "I take part in a winter skiing holiday" is also more typical for men, as $11.9 \%$ of respondents answered with "mostly true", $22.3 \%$ of them with "completely true". At the same time $8.9 \%$ of women answered with "mostly true", and $16.3 \%$ of them with "completely true" (chi2 $=1195.8, \mathrm{df}=10, \mathrm{p}=0.000$ ).

Contextual studies have shown that sporting activities during holidays and sporting leisure activities also tend to dominate men's travel motivation over women. This result may not be surprising, as studies of leisure or sporting habits have found in different populations that men are more active, that is, they will be more active during the holidays (Herpainé et al., 2017; Boda et al., 2019; Kovács, 2011, 2017, 2019, Laoues et al., 2019; Eurobarometer, 2014, 2018) and passive sports consumption, that is, spectating sport events is also a dominant trend among men (Bácsné et al., 2019).

\section{Conclusions}

The needs of travelers are changing, instead of passive travel, active leisure time activities are getting more prevalent during travel. As health-conscious behavior increases, guests will also need recreational activities during their travels, where sport plays a central role.

The survey found that the European continent remains the most popular destination for Hungarian travelers, with $71.5 \%$ of respondents choosing to travel to an EU country and $7.5 \%$ to a non-EU but European destination for their holiday. The strengthening of domestic demand was confirmed by the fact that $9.3 \%$ of the respondents have chosen only domestic destination as a tourist destination in the last 2 years. The results of our study also confirmed that the majority of young adults (63.7\%) had participated in sporting activities with some frequency during the past 2 years, which showed different results by gender. In this aspect the greater activity of men can be justified in the field of sporting holidays, as they prefer active holidays and some form of sports in the chosen tourist destination ( $\mathrm{P}=0.000)$. Thus, in men's preference system, active holidays are more prominent. Men are more interested in active and passive forms of sport tourism than women. The most characteristic sporting activities of sporting holidays are swimming and water sports $(22.2 \%)$, cycling (19.4\%) and hiking (11.6\%). In tourism product development, the development of leisure sports supply is extremely important, as it 
offers opportunities for health preservation, entertainment and active recreation (Ráthonyi et al., 2016), which is demanded by the guests, thus influencing the motivation for choosing a destination.

\section{Acknowledgment}

This study was supported by the EFOP-3.6.2-16-2017-00003 project which is financed by the European Union and the European Social Fund.

\section{References}

Alexandris, K., Kouthouris, C., Funk, D., \& Giovani, C. (2009). Segmenting winter sport tourists by motivation: The case of recreational skiers. Journal of Hospitality Marketing \& Management, 18(5), 480-499.

Bácsné, B. É., Balogh, R., Bács, B. A., Molnár, A., Fenyves, V., \& Müller, A. (2019). The Motivations of Passive Sport Consumption from Gender Perspective. Economica, 10(1), 30-35.

Bánhidi, M. (2007). Sportscience and tourism. Hungarian Review of Sport Science, 30(2), 32-38.

Bánhidi, M. (2015). The model of sport tourism and the analyzation of its elements. In: Laczkó, T., Bánhidi, M. (ed.) Basics of healt and sports tourism. Pécs, Magyarország : University of Pécs Faculty of Health Sciences (PTE ETK), pp. 24-38.

Bansal, H., \& Eiselt, H. A. (2004). Exploratory research of tourist motivations and planning. Tourism Management, 25(3), 387-296.

Bíró, M. (2011). History of recreationaly swimming. Recreation, 1(1), 14-19.

Bíró, M., \& Müller, A. (2017). Active relaxation, recreation. In: Dobos, A., \& Mika, J. - Natural and cultural heritage in the Eger Region. Eger, Magyarország: Líceum Kiadó, pp. 128-130.

Biró, M., Fügedi, B., \& Révész, L. (2007). The Role of Teaching Swimming in the Formation of a Conscious Healthy Lifestyle. International Journal of Aquatic Research and Education 1(3), 269-284.

Biró, M., Müller, A., Ráthonyi-Ódor, K., Ráthonyi, G., Bácsné Bába É., \& Dobay, B. (2017). The Legacy of the Olympic Games, Particularly with Regard to Economic and Social Effects. Selye e-studies, 8(1), 51-63.

Biró, M., Pucsok, J. M., Hidvégi, P., Molnár, A., Mikhárdi, S., \& Lenténé, P. A. (2019b). Analysis of Characteristics, Visitor Turnover and Bathing Services in Hungaryand the North Great Plain Region. In: Balogh, L. (ed.) Sport and Society. Debrecen, Magyarország : University of Debreceni Sports Scientific Coordination Institute, pp. 18-28. , 11 p.

Biró, M., Tatár, A., Pucsok, J. M., Lenténé, P. A., Mikhárdi, S., Hidvégi, P. \& Molnár, A. (2019a). The Health Tourism trends in the North Great Plain Hotels in Hungary. In: Balogh, László (ed.) Multifaced Sports Science, Debrecen, Magyarország: University of Debreceni Sports Scientific Coordination Institute, pp. 9-20, 12 p.

Boda, E. J., Bácsné, B. É., Laoues-Czimbalmos, N., \& Müller, A. (2019). The Analysation of leisure consumer habits among young adults. Special Treatment, 5(4), 33-44.

Boda, E., Bácsné, B. É., Szabados, Gy., \& Müller, A. (2018). The Place of Domestic Adventure Parks in the Sports Services, in Connection with University Student's Research. Studia Mundi - Economica, 5(3), 34-45.

Borbély, A., \& Müller, A. (2015). Sport and tourism. Debrecen, Magyarország : Campus Kiadó, 110 p. ISBN: 9789639822368

Bottero, M., Sacerdotti, S. L., \& Mauro, S. (2012). Turin 2006 Olympic Winter Games: impacts and legacies from a tourism perspective. Journal of Tourism and Cultural Change, 10(2), 202-217.

Buckley, R. (2012). Rush as a key motivation in skilled adventure tourism: Resolving the risk recreation paradox. Tourism management, 33(4), 961-970.

Chang, L. L., F. Backman, K., \& Chih Huang, Y. (2014). Creative tourism: a preliminary examination of creative tourists' motivation, experience, perceived value and revisit intention. International Journal of Culture, Tourism and Hospitality Research, 8(4), 401-419.

Chen, J. S. (1998). Travel motivation of heritage tourists. Tourism Analysis, 2(3-4), 213-215. 
Csirmaz, É., \& Pető, K. (2015). International trends in recreational and wellness tourism. Procedia economics and finance, 32, 755-762.

Dansero, E., \& Puttilli, M. (2010). Mega-events tourism legacies: the case of the Torino 2006 Winter Olympic Games-a territorialisation approach. Leisure Studies, 29(3), 321-341.

Darabos, É. (2015). Role of Tourism in the World Economy; Evolution of Numbers and Wages of Employees in the Sector in Hungary. Acta Oeconomica Universitatis Selye, 4(1), 42-50.

Dobay, B., \& Bánhidi, M. (2013). Analysis of the historical background and development of ski-tourism in the High Tatras Mountains. Hungarian Review of Sport Science, 14(55), 17-22.

Dobay, B., Bánhidi, M., \& Šimonek, J. (2018). Effects of outdoor education on traveling habits of adults in Slovakia and Hungary. Journal of Physical Education and Sport, 18(2), 731-738.

Dobay, B., Kalmár, Zs., Bollók, S., Benczenleitner, O., \& Jančoková, L’. (2011). Research of the motivational background of the sport tourism. Journal of Health Promotion and Recreation, 1(4), 4-11.

Gibson, H. (2006). Sport tourism: Concepts and theories, Routledge, London.

Gibson, H. J. (1998). Sport tourism: a critical analysis of research. Sport management review, 1(1), 45-76.

Gibson, H. J. (2003). Sport tourism: An introduction to the special issue. Journal of Sport Management, 17(3), 205-213.

Gibson, H. J., Attle, S. P., \& Yiannakis, A. (1998). Segmenting the active sport tourist market: A life-span perspective. Journal of Vacation Marketing, 4(1), 52-64

Gibson, H. J., Kaplanidou, K., \& Kang, S. J. (2012). Small-scale event sport tourism: A case study in sustainable tourism. Sport Management Review, 15(2), 160-170.

Gnoth, J. (1997). Tourism motivation and expectation formation. Annals of Tourism research, 24(2), 283-304.

Gődény, N., Biró, M., Lenténé, P. A., Lente, L., \& Müller, A. (2018). Examination of Current Fitness Consumer's Habits and Fitness Trends. In: Balogh, L. (ed.) Health in focus. Debrecen, Magyarország: University of Debreceni Sports Scientific Coordination Institute, pp. 9-18.

Hall, C. M. (1992). Hallmark tourist events: impacts, management and planning. Belhaven Press.

Herman, G. V., Deac, A. L., Ciobotaru, A. M., Andronache, I. C., Loghin, V., \& Ilie, A. M. (2017). The role of tourism in local economy development. Bihor County case study. Urbanism. Architecture. Constructions/Urbanism. Arhitectura. Constructii, 8(3), 265-274.

Herman, G. V., Peptenatu, D., Grama, V., \& Pintilii, R. D. (2018). Tourism and Local Development. Study Case: Băile Felix-Băile 1 Mai Tourism System, Bihor County, Romania. Analele Universitatii din Oradea, Seria Geografie, 28(1), 131-137.

Herpainé, L. J., Simon I. Á., Nábrádi, Zs., \& Müller, A. (2017). The socio-economic background of sporting habits among families. Training and Practice, 15(4), 37-52.

Hinch, T. D., \& Higham, J. E. S. (2001). Sport tourism: a Framework for research. International Journal of Tourism Research, 3, 45-58.

Hudson, S. (2012). Sport and adventure tourism. Routledge.

Ilie, A. M., Herman, G. V., Ciobotaru, A. M., Grecu, A., Radu, R. A., Visan, M. C., \& Giurgia, M. (2017). The Role of Tourism in Structural Dynamics of the Economic Profile of Sighisoara City. Urbanism. Architecture. Constructions/Urbanism. Arhitectura. Constructii, 8(4), 377-386.

Kalmárné, R. Cs., Lengyel, A., \& Hering, K. (2016). The role of travel decision influencing motivations in the tourism services market. Reality: Social Science Bulletin, 59(12), 43-55.

Kovács, K. (2011). Free time and Sport at the University of Debreceni. School Culture, 10(11), 147-162.

Kovács, K. (2017). Socio-cultural and demographical influential factors on physical activity patterns of people above the age of 50. Hungarian Review of Sport Science, 18(72), 32-39.

Kovács, K. (2019). Socio-cultural characteristics of sport activity among students in Central and Eastern Europe: Comparative empirical analysis. Journal of Physical Education and Sport, 19(1), 669- 676.

Kurtzman, J. (2005). Sports tourism categories. Journal of Sport \& Tourism, 10(1), 15-20.

Laoues-Czimbalmos, N., Dobay, B., \& Müller, A. (2019). Examination of the leisure time-related consumption habits of young people with disabilities with special emphasis on sports. Selye EStudies, 10(2), 34-45.

Lengyel, A. (2015). Extending tourism's role in the tourism - meditation - creativity - innovation sustainability trajectory. In: Dunay, A. (ed.) Proceedings of the 5th International Conference on Management 2015: Management, Leadership and Strategy for SMEs' Competitiveness. Gödöllő, Magyarország : Szent István Egyetemi Kiadó, 543-548. 
Lengyel, A. (2019). The Appreciation of Mindfulness and Liminality: Spiritual Retreat Centers, Destinations for a Sustainable Future?, Tourism Bulletin, 19(1), 14-24.

Lengyel, A., Kovács, S., Müller, A., Dávid, L., Szőke, S., \& Bácsné Bába, É. (2019). Sustainability and Subjective Well-Being: How Students Weigh Dimensions. Sustainability, 11(23), 6627.

Lenténé, P. A., Bíró, M., Hídvégi, P., Molnár, A., Lente, L., \& Pucsok J. M.. (2019d). Analysis of the North Great Plain Region's Accommodation Supply with Special Focus on Sport and Wellness Elements. Geosport for Society, 10(1), 15-24.

Lenténé, P. A., Hídvégi, P., Pucsok, J. M., Dobay, B., Molnár, A., \& Bíró, M. (2019c). The analysis of leisure sport's demand and supply elements in the health tourism of the North Great Plain Region. Special Treatment, 5(4), 45-54.

Lenténé, P. A., Hidvégi, P., Tatár, A., Bíró, M., \& Pucsok, J. M. (2019b). A fürdős és medencés szolgáltatások megjelenése az Észak-alföldi régió szállodáiban. In: Balogh, L. (ed.) Multifaced Sports Science. Debrecen, Magyarország : University of Debreceni Sports Scientific Coordination Institute, 54-62.

Lenténé, P. A., Tatár, A., Lente, L., Pucsok, J., Bíró, M., \& Hidvégi, P. (2019a). The Appearance of Sport and Wellness Elements in the Offer of Three, Four And Five Star Hotels in the North Great Plain Region. In: Bácsné, B. É., Müller, A. (ed.) "Movement for health" The importance of physical activity in health protection of future workers: International Conference and Workshop: Proceedings from the International Conference and Workshop. Debrecen, Magyarország: Debreceni Egyetem, 204-215.

Mahika, E. C. (2011). Current trends in tourist motivation. Cactus Tourism Journal, 2(2), 15-24.

Matter-Walstra, K., Widmer, M., \& Busato, A. (2006). Seasonal variation in orthopedic health services utilization in Switzerland: The impact of winter sport tourism. BMC health services research, 6(1), 25.

Michalkó G., Rátz T., Irimiás A. \& Pagini, A. (2011). Aspects of the relationship between health tourism and quality of life in Hungary, pp. 27-43. In: Michalkó, G., \& Rátz, T. (ed.). Health tourism and quality of life in Hungary: Chapters on the connection between health, travel and well-being in Hungary. MTA Geographical Research Institute., Budapest, 179 p.

Michalkó, G. (2002). The theoretical approach of active tourism. In: Dávid, L. (ed.) Active tourism. Debrecen. Magyarország : Didakt Kiadó, 5-16.

Michalkó, G., \& Vizi, I. (2002). The role of recreation in active tourism. Hungerian Review of Sports Science, 3(3-4),19-23.

Mosonyi, A., Könyves, E., Fodor, I., \& Müller, A. (2013). Leisure activities and travel habits of College students in the light of a survey, Abstract - Applied Studies In Agribusiness And Commerce, 7(1), 57-61.

Müller, A. (2009). Analysis of the supply elements of leisure activities in the development of health conscious behavior. Habilitation, University of Debreceni, Debrecen. 2009.

Müller, A., \& Bácsné, B. É. (2018). The connection of sports and healthy lifestyle. Létavértes, Magyarország: Létavértes SC '97 Egyesület, 96 p.

Müller, A., \& Kórik, V. (2009). The role of the Nort Great Plain Spas in tourism and recreation. Economica, 2, 58-72.

Müller, A., \& Szabó, R. (2009). Analysis of Agárd, Komárom and Papa's Thermal bath, According the Guest's satisfaction. Acta Academiae Paedagogicae Agriensis Nova Series: Sectio Sport, 36, 89-101.

Müller, A., Bács, Z., Bácsné, B. É., Oláh, J., Pfau, C., \& Molnár, A. (2019). Comparative Analysis of Equestrian Facilities in the North Great Plain Region. International Journal of Engineering and Management Sciences, 4(3), 79-93.

Müller, A., Bíró, M., Ráthonyi-Odor, K., Ráthonyi, G., Széles, K. Gy., Boda, E., Macra-Osorhean, M. D., \& Andras, Á. (2016). Economic impacts of sports events. Studia Universitatis Babes-Bolyai Educatio Artis Gymnasticae, LXI, 4, 85-95.

Müller, A., Könyves, E., \& Szabó, R. (2005). The introduction of the diverse supply of wellnesstourism. Physical Education and Sports - Theoretical Methodological and Information Journal, 27, 29-34.

Müller, A., Szabó, R., Kerényi, E., \& Mosonyi, A. (2009). Bath Research in the Central Trans-Danubian Region. Acta Academiae Paedagogicae Agriensis Nova Series: Sectio Sport, 36, 77-87.

Müller, A., Széles, K. Gy., Seres, J., Kristonné, B. M. (2011). The recreational activities of college students. Rekreacio.eu 1, 4, 31-34.

Müller, A., Széles-Kovács, Gy., Seres, J., Bocz, Á., Hajdú, P., Sütő, L., Szalay, G., Szabó, B., \& Juhász, I. (2007). Role of the Sports Camps in the Eszterházy Károly College. Acta Academiae Paedagogicae Agriensis Nova Series: Sectio Sport, 34, 105-117. 
Ráthonyi, G., Bácsné, B. É., Müller, A., \& Ráhonyi-Odor, K. (2018). How Digital Technologies Are Changing Sport?. Apstract - Applied Studies In Agribusiness And Commerce, 13 (3-4), 89-96.

Ráthonyi, G., Bácsné, B. É., Müller, A., \& Ráthonyi-Odor, K. (2019). IT Soultions in connection with enhancgin fan experience In: Balogh, L. (ed.) Multifaced Sports Science, Debrecen, Magyarország: University of Debreceni Sports Scientific Coordination Institute, 98-107.

Ráthonyi-Odor, K., Ráthonyi, G., \& Borbély, A. (2016). It's good to play sports - responsibly for promoting sport. Acta Agraria Debreceniensis, 67, 71-76.

Ritchie, B. W., Tkaczynski, A., \& Faulks, P. (2010). Understanding the motivation and travel behavior of cycle tourists using involvement profiles. Journal of Travel \& Tourism Marketing, 27(4), 409-425.

Robinson, T., \& Gammon S. (2004). A question of primary and secondary motives: Revisiting and applying the sport tourism framework. Journal of Sport Tourism, 9 (3), 221-223.

Smith, M. \& Puczkó L. (2010). Health tourism: medicine, wellness, holistics. Academic Press, Budapest, 427 p. ISBN: 978-963-05-8806-5

Sőrés, A., Pető, K., \& Csipkés, M. (2012). Examining life quality in Hajdúszoboszló Tourist Area, with a special focus on health conditions. Journal of Agricultural Informatics, 3(1), 1-9.

Sulyok, J., Magyar, Zs. (2014). The situation of active tourism in Hungary - Hiking and biking in focus. Tourism Bulletin XVI (3-4), 15-26.

Weed, M., \& Bull, C. (1997). Influences on sport tourism relations in Britain: the effects of government policy. Tourism Recreation research, 22 (2), 5-12.

\section{Web-sites sources:}

Biró, M., Hidvégi, P., Kopkáné-Plachy J., Széles-Kovács, Gy., \& Váczi, P. (2015). Leisure sports. http://uni-eger.hu/public/uploads/szabadidosportok_5551e3b1472b4.pdf

European Commission. Special Eurobarometer 412 - Sport and physical activity. 2014. http://ec.europa.eu/commfrontoffice/publicopinion/archives/ebs/ebs_412_en.pdf (accessed at: 2019. 12.16.)

European Commission. Special Eurobarometer 472 - Sport and physical Activity. 2018. https://ec.europa.eu/sport/news/2018/new-eurobarometer-sport-and-physical-activity_en (accessed at: 2019. 12.16.)

Hudson, S. (2003). Sport and Adventure tourism. The Haworth Hospitality Press. USA. http://www.google.hu/books?hl=hu\&lr=\&id=1vVtyaA77YsC\&oi=fnd\&pg=PR3\&dq=Hudson, + S., +20 $03+$ sport+tourism\&ots=7LmV3Y_Dek\&sig=0npoU2RJ8WanRcpozFCMFrzfJWs\&redir_esc $=y \# v=o n e$ page\&q\&f=false

KSH (2018): Situational picture of the tourism and catering sectors, 2018. https://www.ksh.hu/docs/hun/xftp/idoszaki/jeltur/jeltur18.pdf, (accessed at: 2019. 12.19.)

Lövei-Kalmár, K. (2017). The importance of baths in the development of the Northern Great Plain Region's health tourism. Intermediate Europe. (9) 1-2. 205-213.p. http://acta.bibl.uszeged.hu/55037/1/koztes_europa_2017_001_002_205-213.pdf

Tourism Towards 2030. Global Overview: https://www.globalwellnesssummit.com/wpcontent/uploads/Industry-Research/Global/2011_UNWTO_Tourism_Towards_2030.pdf (accessed at: 2019.11.27.)

$\begin{array}{lllll}\text { UNWTO (2019): } & \text { International } & \text { Tourism } & \text { Highlights } & \end{array}$ https://www.eunwto.org/doi/pdf/10.18111/9789284421152 (accessed at: 2020.01.09.)

UNWTO 2018: UNWTO Tourism Highlights 2018 edition. https://www.eunwto.org/doi/pdf/10.18111/9789284419876, (accessed at: 2019. 12.19.) 